\title{
Short communication: Proteins from circulating exosomes represent metabolic state in transition dairy cows
}

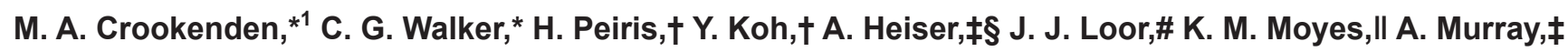 \\ V. S. R. Dukkipati,ł J. K. Kay,ף S. Meier,ף J. R. Roche,ף and M. D. Mitchell† \\ *DairyNZ, 3A Symonds Street, Auckland 1010, New Zealand \\ †University of Queensland, Centre for Clinical Research, Herston, Queensland 4029, Australia \\ łInstitute of Vet, Animal and Biomedical Sciences, Massey University, Palmerston North 4442, New Zealand \\ $\S A g R e s e a r c h$, Hopkirk Research Institute, Palmerston North 4442, New Zealand \\ \#Department of Animal Sciences, University of Illinois, Urbana 61801 \\ IIDepartment of Animal and Avian Sciences, University of Maryland, College Park 20742 \\ IDairyNZ, Cnr Ruakura \& Morrinsville Rds (SH26), Newstead, Hamilton 3284, New Zealand
}

\begin{abstract}
Biomarkers that identify prepathological disease could enhance preventive management, improve animal health and productivity, and reduce costs. Circulating extracellular vesicles, particularly exosomes, are considered to be long-distance, intercellular communication systems in human medicine. Exosomes provide tissue-specific messages of functional state and can alter the cellular activity of recipient tissues through their protein and microRNA content. We hypothesized that exosomes circulating in the blood of cows during early lactation would contain proteins representative of the metabolic state of important tissues, such as liver, which play integral roles in regulating the physiology of cows postpartum. From a total of 150 cows of known metabolic phenotype, 10 cows were selected with high $(\mathrm{n}=5$; high risk) and low $(\mathrm{n}=5$; low risk) concentrations of nonesterified fatty acids, $\beta$-hydroxybutyrate, and liver triacylglycerol during wk 1 and 2 after calving. Exosomes were extracted from blood on the day of calving (d 0) and postcalving at wk 1 and wk 4, and their protein composition was determined by mass spectroscopy. Extracellular vesicle protein concentration and the number of exosome vesicles were not affected by risk category; however, the exosome protein cargo differed between the groups, with proteins at each time point identified as being unique to the highand low-risk groups. The proteins $\alpha-2$ macroglobulin, fibrinogen, and oncoprotein-induced transcript 3 were unique to the high-risk cows on d 0 and have been associated with metabolic syndrome and liver function in humans. Their presence may indicate a more
\end{abstract}

\footnotetext{
Received December 20, 2015.

Accepted May 9, 2016.

${ }^{1}$ Corresponding author: mallory.crookenden@dairynz.co.nz
}

severe inflammatory state and a greater degree of liver dysfunction in the high-risk cows than in the low-risk cows, consistent with the high-risk cows' greater plasma $\beta$-hydroxybutyrate and liver triacylglycerol concentrations. The commonly shared proteins and those unique to the low-risk category indicate a role for exosomes in immune function. The data provide preliminary evidence of a potential role for exosomes in the immune function in transition dairy cows and exosomal protein cargo as biomarkers of metabolic state.

Key words: exosome, metabolic state, lactation extracellular vesicle

\section{Short Communication}

During the peripartum period, cows are at greater risk of metabolic and infectious disease. This is evident by an increase in the incidence of health events; an estimated $50 \%$ of cows experience at least one disease during the transition period (LeBlanc, 2010). Identification of individuals at risk of metabolic dysfunction could provide potential for preventive intervention (Ingvartsen et al., 2003; Halasa et al., 2007).

Exosomes are small, membrane-bound extracellular vesicles (ECV; 40-100 $\mathrm{nm}$ in diameter) exocytosed by cells. They contain components from the propagating cell (Simpson et al., 2009; Mathivanan et al., 2010), including proteins (Looze et al., 2009), lipids (Subra et al., 2007), and various nucleic acids (Gallo et al., 2012), and are hypothesized to regulate the function of target cells throughout the body (Denzer et al., 2000). Aberrant cellular function (particularly pathologic conditions) can alter the rate of release of ECV (Kim et al., 2003; Baran et al., 2010) as well as their protein composition, such that the contents reflect the physiological state of the originating cell (Mathivanan et al., 2010). Furthermore, as ECV are transported in blood 
as long-distance, intercellular messengers, they are potential biomarkers of disease state (Distler et al., 2006; Taylor and Gercel-Taylor, 2008). For example, tumorderived exosomes contain different protein contents compared with those secreted from nonmalignant cells (Andre et al., 2002). Furthermore, proteomic investigation of bovine milk exosomes has revealed that these nanoparticles are important for cellular communication in bovines during lactation, particularly for lactation physiology and mammary immune function (Reinhardt et al., 2012, 2013).

Due to the reported link between disease pathogenesis and circulating ECV proteins, we hypothesized that exosomes isolated from cows at risk of metabolic dysfunction during the transition period will exhibit an altered protein composition and, if so, could be useful biomarkers of health. In the current study, exosomes were isolated from the plasma of 2 cohorts of cows identified as being either a low or high risk for metabolic dysfunction postcalving, and their protein content characterized using mass spectroscopy.

The Ruakura Animal Ethics Committee (Hamilton, New Zealand) approved all animal manipulations (RAEC\#12799) in accordance with the New Zealand Animal Welfare Act (1999). The experiment was undertaken at Scott Farm, Hamilton, New Zealand $\left(37^{\circ} 46^{\prime} \mathrm{S}\right.$ $175^{\circ} 18^{\prime} \mathrm{E}$ ) between July and October 2013.

Cows used in this study were part of a larger experiment ( $\mathrm{n}=150$; Roche et al., 2015). From this larger group, 10 cows were identified as being at either high risk $(\mathbf{H R} ; \mathrm{n}=5)$ or low risk $(\mathbf{L R} ; \mathrm{n}=5)$ of metabolic dysfunction based on blood plasma nonesterified fatty acid (NEFA; mmol/L) and BHB (mmol/L), and liver triacylglycerol (TAG; \% of liver wet weight) after calving. The HR group cows exhibited higher $(P<0.01)$ mean $( \pm \mathrm{SD})$ values for the 3 variables than those in the LR group during wk 1 (d $4 \pm 2)$ and wk 2 (d 11 \pm 2 ) postcalving: 1.80 versus $0.66 \pm 0.32,1.00$ versus $0.45 \pm 0.25$, and 9.0 versus $1.8 \pm 1.59$, for NEFA, BHB, and TAG respectively, during wk 1 postcalving, and 1.20 versus $0.30 \pm 0.33,0.86$ versus $0.48 \pm 0.11$, and 10.3 versus $1.4 \pm 1.59$, for NEFA, BHB, and TAG, respectively, during wk 2 . Average milk yield $(P<0.05)$, fat percentage $(P=0.2)$, and protein percentage $(P<$ $0.05)$ during wk 1 and 2 of lactation for the HR and LR groups were $23.6 \mathrm{~kg}, 5.0 \%$, and $3.9 \%$, and $18.4 \mathrm{~kg}$, $4.2 \%$, and $4.2 \%$, respectively.

Blood samples for metabolite analysis (wk 1 and 2) and exosome extraction (d 0, wk 1, and wk 4) were collected by coccygeal venipuncture into evacuated blood tubes containing either heparin or EDTA anticoagulant, respectively. Blood was placed immediately on ice and centrifuged at $1,500 \times g$ for $12 \mathrm{~min}$ at $4^{\circ} \mathrm{C}$; then, the plasma was aspirated and stored at $-20^{\circ} \mathrm{C}$ until assayed. Approximately $1 \mathrm{~g}$ (wet weight) of liver tissue was collected (wk 1 and 2) for TAG analysis as outlined by Lucy et al. (2009). Collected liver samples were snap-frozen in liquid nitrogen and stored at $-80^{\circ} \mathrm{C}$.

Metabolite analysis and liver TAG assays were undertaken by Gribbles Veterinary Pathology Ltd. (Hamilton, New Zealand). Plasma BHB (mmol/L) was assayed with a Roche reagent kit using colorimetric techniques on a Hitachi Modular P800 analyzer at $37^{\circ} \mathrm{C}$ (Roche Diagnostics). Plasma NEFA concentrations $(\mathrm{mmol} / \mathrm{L})$ were measured using Wako Chemicals kit (Osaka, Japan). Liver TAG content was analyzed using the Wako LabAssay Triglyceride kit (290-63701, Wako Chemicals USA Inc., Richmond, VA). For detailed analysis, refer to Roche et al. (2015).

Exosomes were isolated from plasma $(1 \mathrm{~mL})$ at $\mathrm{d} 0$, wk 1, and wk 4 by ultracentrifugation as previously described (Salomon et al., 2014a; Sarker et al., 2014). In brief, plasma was diluted with an equal volume of PBS (pH 7.4) and centrifuged at 2,000 $\times g$ for $30 \mathrm{~min}$ at $4^{\circ} \mathrm{C}$; then, the supernatant was removed and centrifuged at $12,000 \times g$ for $45 \mathrm{~min}$ at $4^{\circ} \mathrm{C}$ (Sorvall, highspeed microcentrifuge, fixed rotor angle: 900, Thermo Fisher Scientific Inc., Asheville, NC). The resulting supernatant was transferred to an ultracentrifuge tube and centrifuged at $100,000 \times g$ for $75 \mathrm{~min}$. The pellet was resuspended in PBS $(30 \mathrm{~mL})$, filtered through a $0.22-\mu \mathrm{m}$ filter, and then centrifuged at $100,000 \times g$ for $75 \mathrm{~min}$. The resulting pellet was resuspended in PBS $(500 \mu \mathrm{L})$, layered on a discontinuous iodixanol gradient, and 12 fractions were collected, diluted with PBS, and centrifuged at $100,000 \times g$ for $2 \mathrm{~h}$ at $4^{\circ} \mathrm{C}$. Finally, the pellet containing the enriched exosome population was resuspended in $50 \mu \mathrm{L}$ of PBS. After isolation, exosomes were characterized by the size distribution, presence of endocytic marker (i.e., TSG101 and CD63), and morphology by nanoparticle tracking analysis, Western blot, and electron microscopy, respectively. Concentration of ECV was determined by using the DC Protein Assay (Bio-Rad, Hercules, CA). To ascertain the number of exosomal vesicles (NEV) per milliliter of plasma, a commercially available kit was used following manufacturer's instructions (ExoEL-CD63A-1; ExoELISA kit, System Biosciences, Mountain View, CA). Briefly, exosome concentration was determined as total immunoreactive exosomal CD63, and NEV per milliliter was calculated using ECV concentration.

To determine protein composition within exosomes, a modified version of the method described by Salomon et al. (2014b) was used. Isolated exosomes from plasma were sonicated for $15 \mathrm{~min}$ and samples were diluted in $50 \mathrm{~m} M$ ammonium bicarbonate, $\mathrm{pH}$ 8.5, and reduced with dithiothreitol for $1 \mathrm{~h}$. Proteins were then alkylated in $10 \mathrm{~m} M$ iodoacetic acid for $1 \mathrm{~h}$ in the dark. 
The sample was diluted 1:10 with $50 \mathrm{~m} M$ ammonium bicarbonate and digested with trypsin $(1 \mu \mathrm{g}$ of trypsin:20 $\mu \mathrm{g}$ of protein; Promega, Madison, WI) at $37^{\circ} \mathrm{C}$ for $18 \mathrm{~h}$. The samples were then desalted by solid-phase extraction using a STAGE tip protocol [stop and go extraction tips for matrix-assisted laser desorption/ ionization, nano-electrospray, and liquid chromatography (LC)-MS sample pretreatment in proteomics]. The eluted peptides were dried by centrifugal evaporation to remove acetonitrile and redissolved in solution A ( $0.1 \%$ formic acid in water). The resulting peptide mixture was analyzed by LC-tandem MS (LC-MS/MS) on a Triple TOF 5600 System mass spectrometer (AB Sciex, Framingham, MA) equipped with an Eksigent Nanoflow binary gradient HPLC system (Eksigent, Redwood City, CA) and a nanospray III ion source. Digested peptides were separated using a ChromXP C18-CL TRAP cHiPLC $(200 \mu \mathrm{m} \times 6 \mathrm{~mm}, 3 \mu \mathrm{m}, 120$ $\AA)$ and analytical cHiPLC columns $(200 \mu \mathrm{m} \times 15 \mathrm{~cm}$; $3 \mu \mathrm{m}, 120 \AA$; Eksigent) using a linear gradient of 5 to $10 \%$ solvent B (acetonitrile/0.1\% formic acid) for 2 min, 10 to $40 \%$ solvent B (58 min), 40 to $50 \%$ solvent B (10 min), 50 to $95 \%$ solvent B (10 min) with a flow rate of $500 \mathrm{~nL} / \mathrm{min}$. The column was flushed at $95 \%$ solvent B for 15 min and re-equilibrated with $5 \%$ solvent $\mathrm{B}$ for $6 \mathrm{~min}$. The MS/MS spectra were collected using information dependent acquisition using a survey scan $(m / z 300-2,000$ with an accumulation time of 250 $\mathrm{ms}$ ) followed by 12 data-dependent product ion scans of the 12 most intense precursor ions $(\mathrm{m} / z$ 100-2,000 with an accumulation time of $150 \mathrm{~ms}$ ). The precursor selection criteria included a minimum intensity or 50 counts per second and a charge state greater than $2+$. All mass spectra were analyzed using the Mascot and Protein Pilot search engines against the Swissprot database (http://www.uniprot.org/) with the species set as bovine. Positive identifications were ascribed where Mascot scores were greater than 30 (Supplementary Table S1; http://dx.doi.org/10.3168/jds.2015-10786). False discovery rate was estimated using a reversed sequence database.

To test the effects of risk category, week, and their interaction on protein concentration and NEV, a mixed model approach with repeated-measures ANOVA was used (PROC MIXED; SAS/STAT 12.1, SAS Institute Inc., Cary, NC). This was followed by Tukey's $t$-test for pairwise comparisons. Exosome number data were $\log _{10}$-transformed to achieve homogeneity of variance. Significance was declared if $P<0.05$; results are presented as least squares means \pm standard error of the difference (SED).

The plasma concentration of ECV protein and the NEV in cows categorized as having either a high risk or low risk of metabolic dysfunction during the transition

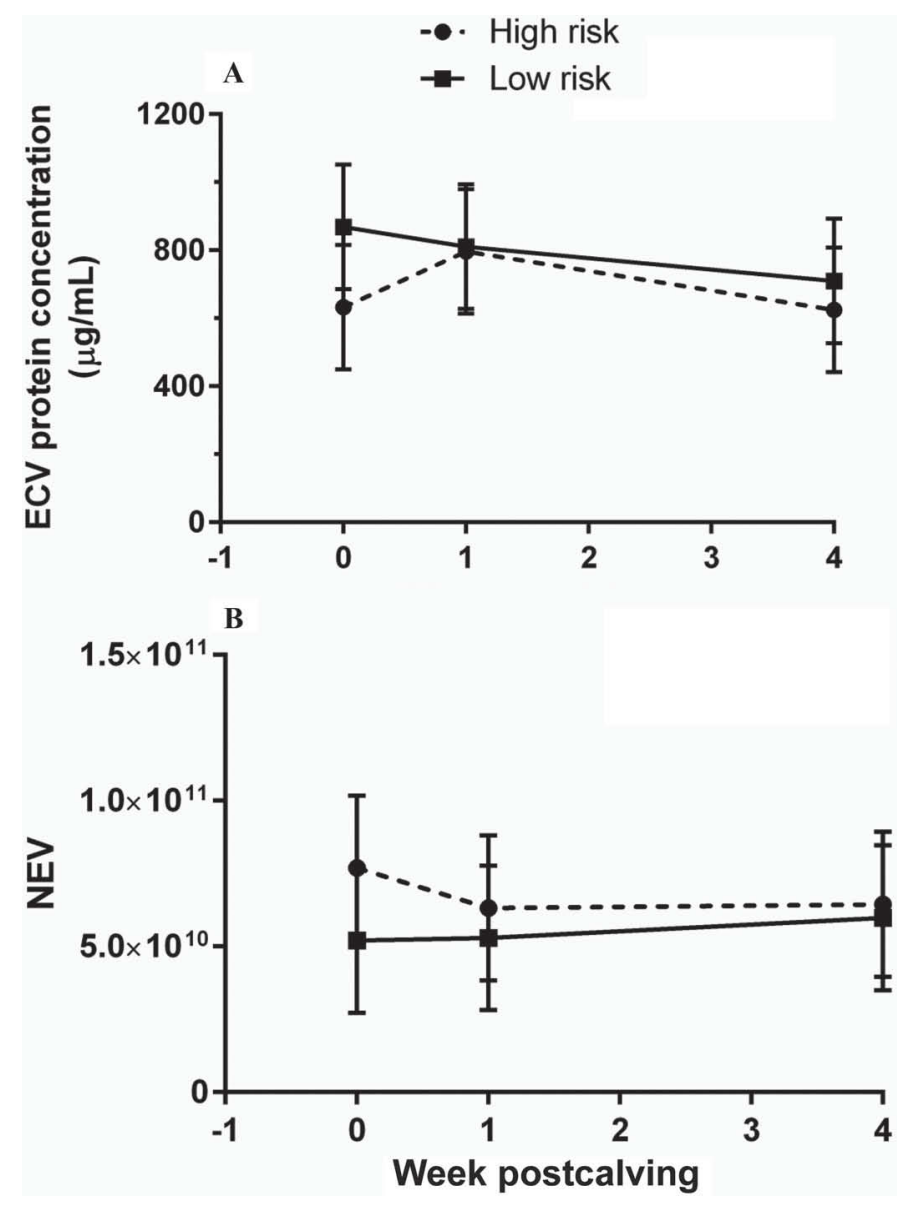

Figure 1. (A) Plasma concentration of total protein $(\mu \mathrm{g} / \mathrm{mL})$ extracted from extracellular vesicles (ECV) and (B) number of exosomal vesicles (NEV) per milliliter of plasma from cows characterized as being at either a high risk $(n=5)$ or low risk $(n=5)$ of metabolic dysfunction during the transition period. Exosome number data were $\log _{10}$-transformed before statistical analysis; back-transformed data are presented for ease of interpretation, and error bars denote \pm SEM.

period are presented in Figure 1. On average, cows had $740 \pm 279.7 \mu \mathrm{g} / \mathrm{mL}$ of ECV protein in blood and $6.7 \pm$ $3.74 \times 10^{10} \mathrm{NEV} / \mathrm{mL}$ of plasma; these concentrations are similar to those measured in other species (from $2 \times 10^{9}$ to $9 \times 10^{12}$ in humans, depending on stage of gestation; Salomon et al., 2014a). We detected no relationship $\left(\mathrm{R}^{2}=0.001\right)$ between ECV protein concentration and $\mathrm{NEV}(P=0.91)$.

Neither protein concentration nor $\log _{10} \mathrm{NEV}$ was affected by risk category $(P=0.50$ and 0.91 , respectively $)$ or week postcalving ( $P=0.28$ and 0.44 , respectively), and there was no interaction between risk category and week postcalving ( $P=0.42$ and 0.79 , respectively). Both ECV protein concentration and NEV reportedly increase in situations of hepatic steatosis and nonalcoholic steatohepatitis (Povero et al., 2014). The lack of a difference in either variable in our results was, 
therefore, somewhat surprising, considering the large differences in circulating NEFA and liver TAG between the risk categories. This might have been due to limited statistical power, with only 5 animals per treatment; future investigations should involve more animals. However, Povero et al. (2014) highlighted that the effect of hepatic steatosis (fatty liver disease) on ECV was progressive, with evident differences in steatosis after $4 \mathrm{wk}$ in a mouse model of diet-induced nonalcoholic fatty liver disease. The diet, high in fat and deficient in choline L-amino acid, failed to result in differences in ECV protein concentration, but further exposure to the diet produced both a greater degree of steatosis and a linear increase in ECV protein with the degenerative liver condition. These results indicate that nonsymptomatic fatty liver in early lactation dairy cows may not be sufficiently severe or of sufficient duration to elevate the concentration of ECV protein or NEV.

Although there was no evident difference in either ECV protein concentration or NEV between risk categories or days postcalving, we identified exosomal protein signatures unique to each risk category (Figure 2 ), suggesting that the exosomal cargo may vary with metabolic state during the transition period. Between 19 and 25 distinct proteins (depending on postcalving time point) were identified from between 44 and 72 individual accession numbers. Details of the exosomal proteins unique to risk categories, as well as those in common, are presented in Table 1 . Of the proteins identified, 8 were unique to the blood exosomes extracted from $\mathrm{HR}$ cows on $\mathrm{d} 0,10$ were unique to cows in the LR category, and 5 were common to both categories (Figure 2). Unique proteins identified in each risk category at each postcalving time point over the transition period are presented in Figure 3. At wk 1 postcalving, 5 proteins were identified as unique to cows in the HR category, 15 to cows in the LR category, and 5 proteins were common to both groups. By wk 4 postcalving, only 4 proteins were unique to cows in the HR category, 12 to the LR category, and 3 proteins were commonly shared.

Several of the exosomal proteins on $\mathrm{d} 0$ and wk 1 postcalving that were unique to cows categorized as being at a high risk of metabolic dysfunction are associated with metabolic syndrome in humans. For example, Feng et al. (2015) identified increased concentrations of $\alpha$-2-macroglobulin in saliva in patients with type II diabetes. Similarly, elevated concentrations of fibrinogen in blood have been extensively associated with metabolic syndrome, cardiovascular disease, and type II diabetes (reviewed by Mertens and Van Gaal, 2002) and as a marker of inflammation in dairy cows (McSherry et al., 1970). Several parallels have been drawn between metabolic syndrome in humans and the biology
High Risk Low Risk
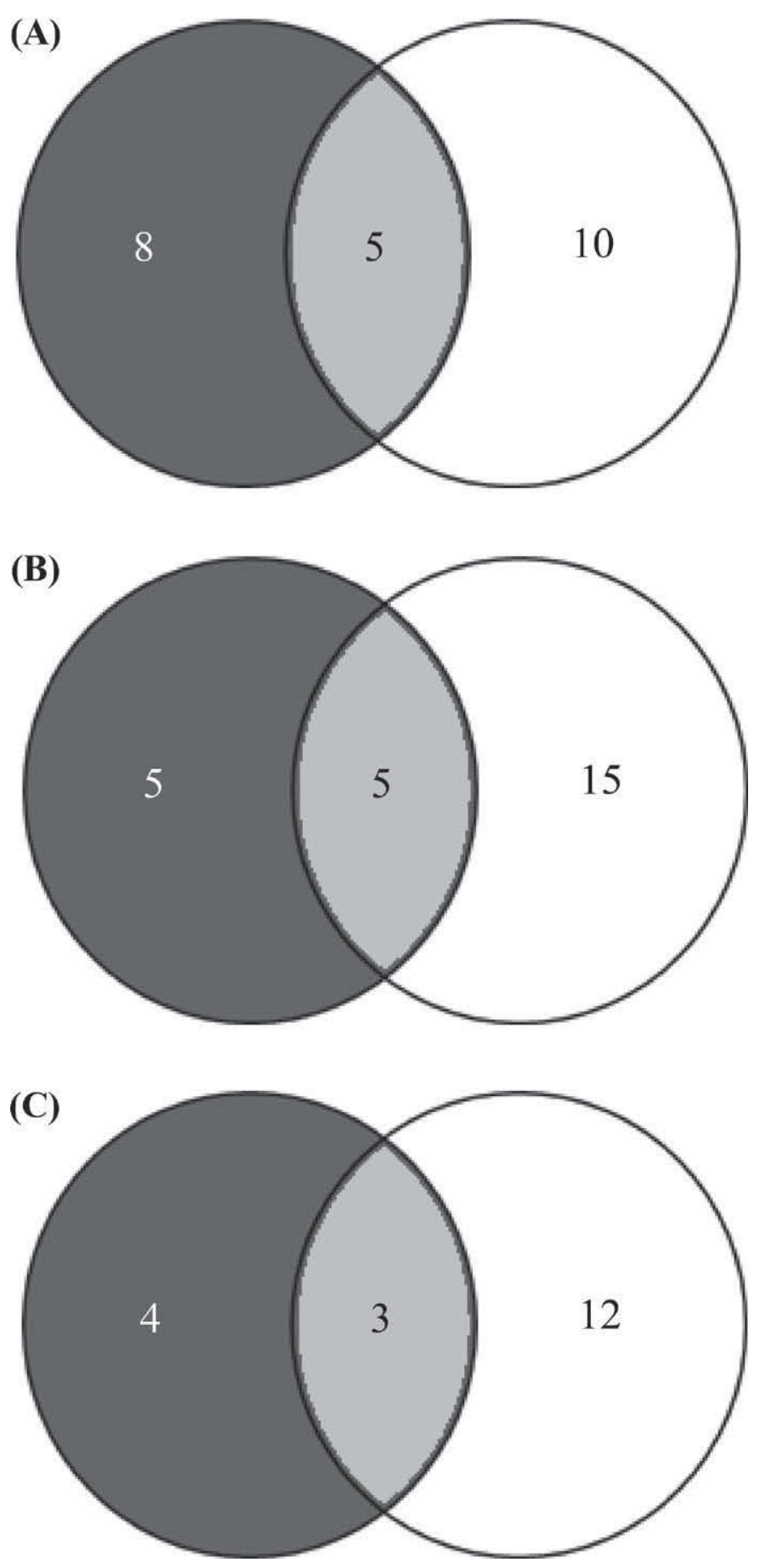

Figure 2. Graphical representation of unique proteins identified in plasma exosomes isolated from cows characterized as being at high risk or low risk of metabolic dysfunction during the transition period based on circulating concentrations of nonesterified fatty acids (NEFA) and BHB and liver triacylglycerol (TAG) at wk 1 and 2 postcalving. (A) Blood sampled on the day of calving (d 0); (B) blood sampled wk 1 postcalving; and (C) blood sampled wk 4 postcalving. Elements unique to high-risk cows are dark gray, those unique to low-risk cows are white, and common elements are light gray. 


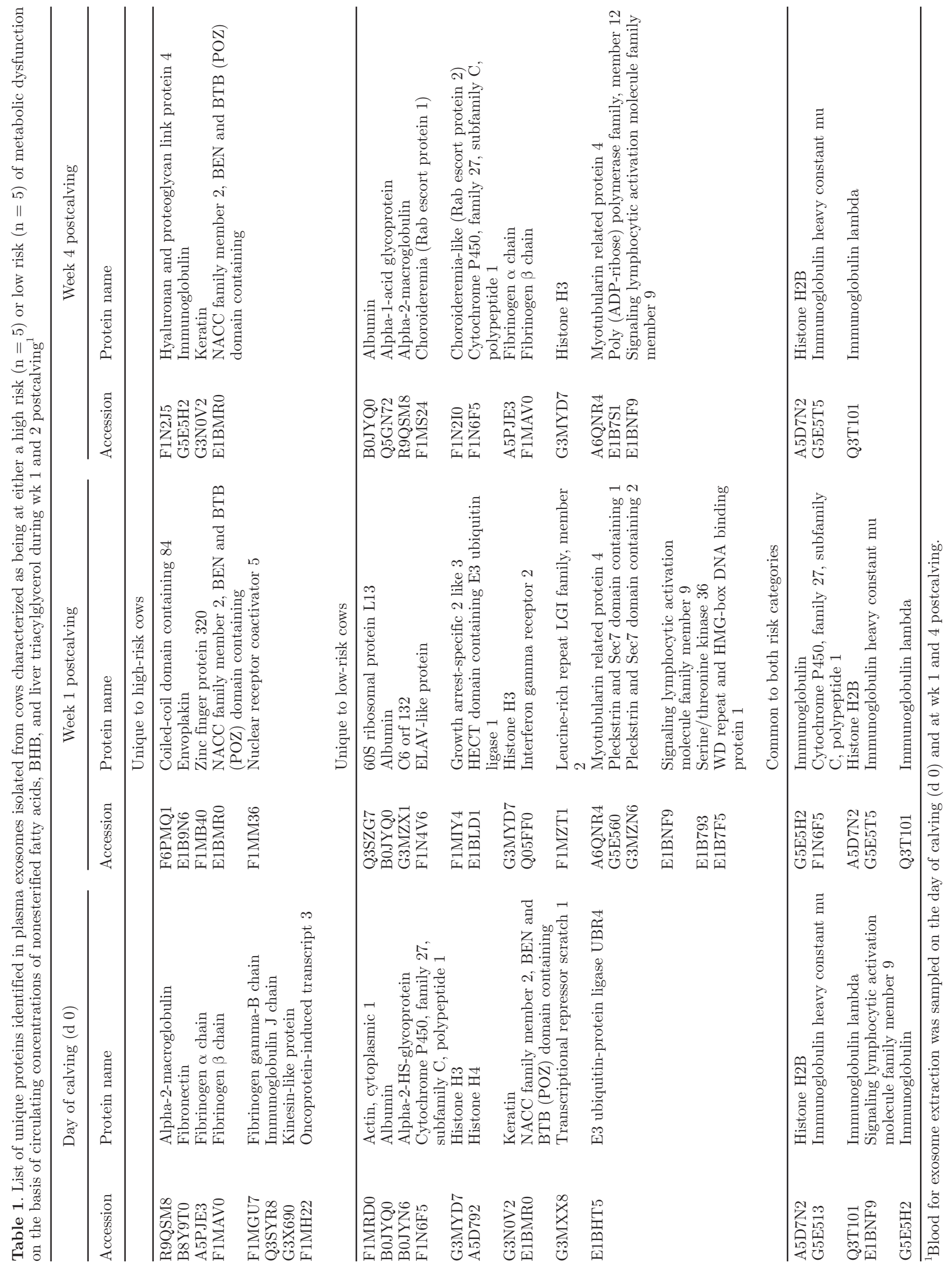


of the postpartum dairy cow (Lucy et al., 2004). For example, chronic inflammation, the presence of insulin resistance, and the resultant increased concentration of NEFA (Chagas et al., 2007; Farney et al., 2013) create a natural link between the endocrine physiology of postpartum cows and the physiology of type II diabetic

(A)
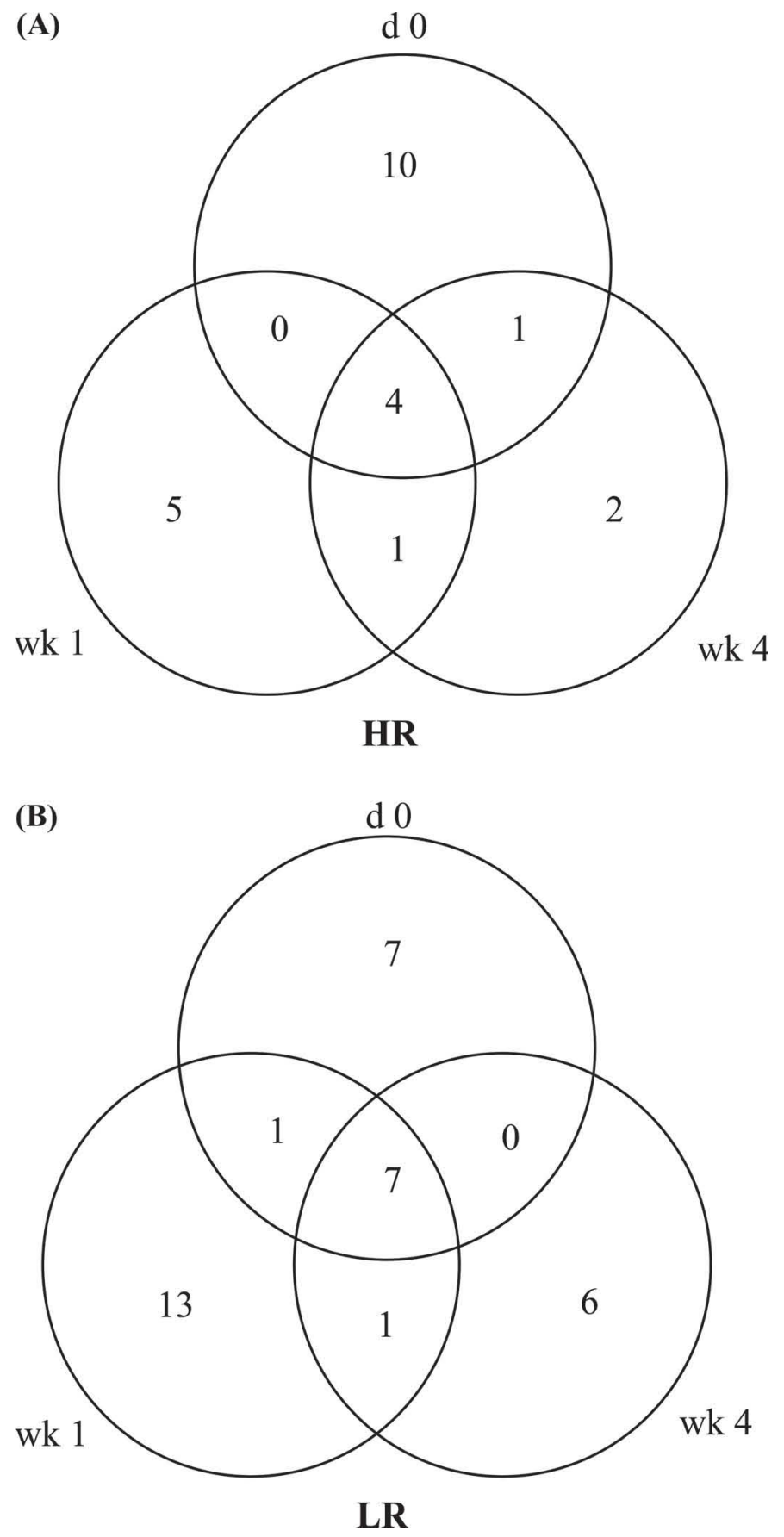

Figure 3. Graphical representation of unique proteins at 3 time points: day of calving (d 0) and wk 1 and wk 4 postcalving in (A) high-risk (HR), and (B) low-risk (LR) cows. states presented in humans (Harris, 2005; Lewis et al., 2002). It is not surprising that the exosome phenotype of the HR cows signified a degree of metabolic dysfunction. Cows in the HR category were chosen because their metabolic profile reflected an extreme tendency to mobilize adipose reserves (i.e., high NEFA), an inability of the liver to oxidize mobilized NEFA completely (i.e., high BHB), and a failure of the liver to export the resultant very low density lipoprotein to peripheral tissues (i.e., high liver TAG).

In addition to these markers of metabolic state, both envoplakin and oncoprotein-induced transcript-3 were elevated in the cows categorized by their metabolic profile as being at increased risk of disease. These proteins have been identified as being important in liver function, with envoplakin isolated from plasma in a human patient with hepatocellular carcinoma (Yokokura et al., 2006) and oncoprotein-induced transcript-3 identified as a protein specific to liver (Shen et al., 2009). It is unclear whether their presence in the exosomes of HR cows reflects metabolic dysfunction or is merely a signature of more metabolically active liver cells indicated by the greater uptake of NEFA and the accumulation of TAG. We propose that these proteins reflect the hepatic steatosis used to characterize these cows and, as such, may be useful biomarkers of a more severe pathological condition before clinical signs are evident.

Although identified by their metabolic profile as being at risk of disease, it is noteworthy that none of these animals succumbed to a clinical condition. This lack of progression to a disease state may also be reflected in their exosome profile. By wk 4, the proteins peculiar to the HR cows were no longer reflective of the metabolic syndrome phenotype, which is consistent with the timing of a return to normal physiological function; for example, the maximum rate of lipolysis has ended (McNamara and Hillers, 1986b; Roche et al., 2007, 2009), the process of lipogenesis has been reinstated (McNamara and Hillers, 1986a), the somatotropic axis has recoupled (Lucy et al., 2009), and most measures of metabolic state and immune function have returned to near precalving baseline concentrations (Bauman and Currie, 1980; Heiser et al., 2015; Roche et al., 2015). Our results provide hints that exosomes could carry a signature of metabolic dysfunction, which, with appropriate characterization, could be used in lieu of a liver biopsy, for example. Further work is required to determine the sensitivity of the exosome protein cargo to the metabolic state of the periparturient cow and whether the signature could be evaluated from noninvasive samples, such as urine, milk, or saliva.

The proteins unique to the LR dairy cows and those in common between groups indicate a role for exosomes in immune function regulation. For example, signal- 
ing lymphocytic activation molecule-9 is a protein involved in regulation of immune cell interactions and is required for normal development, homeostasis, and immune cell function (Volkova et al., 2014). Similarly, the commonality of immunoglobulin proteins is consistent with a role for exosomes in transporting important immune molecules between tissues. Furthermore, $\alpha$-1-glycoprotein is an acute phase protein produced in response to inflammation (Hochepied et al., 2003). It has several immunoregulatory functions, including inhibition of inflammatory responses of several immune cells, such as lymphocytes and neutrophils, indicating a possible role for exosomes in regulating immune function in early lactation (Chiu et al., 1977; TheilgaardMönch et al., 2005).

In conclusion, although ECV protein concentration in blood and NEV did not differ between risk categories in the current experiment and, therefore, would not be suitable for identifying at-risk cows, the exosome protein cargo was different between cows categorized as being at either a high or low risk of metabolic dysfunction during the transition period. The proteins identified as unique to the HR cows were biologically consistent with the metabolic state by which cows were categorized. Further research will endeavor to improve the sensitivity of the LC-MS/MS protocol; however, these preliminary results indicate that exosomal protein cargo may have potential as a biomarker of subclinical disease. Furthermore, additional research is needed to determine if exosome signatures are sufficiently sensitive to identify at-risk cows likely to recover or those likely to suffer clinical disease.

\section{ACKNOWLEDGMENTS}

The authors acknowledge the help afforded by DairyNZ Ltd. (Hamilton, New Zealand) farm and technical staff and the statistical expertise of B. KuhnSherlock. We also acknowledge the Mass Spectrometry Facility at the University of Queensland, Center for Clinical Research (Herston, QLD, Australia). This work was funded by New Zealand dairy farmers, through DairyNZ Inc. (RD1403) and the Ministry of Business, Innovation and Employment (DRCX1201), New Zealand.

\section{REFERENCES}

Andre, F., N. E. C. Schartz, M. Movassagh, C. Flament, P. Pautier, P. Morice, C. Pomel, C. Lhomme, B. Escudier, T. Le Chevalier, T. Tursz, S. Amigorena, G. Raposo, E. Angevin, and L. Zitvogel. 2002. Malignant effusions and immunogenic tumour-derived exosomes. Lancet 360:295-305. http://dx.doi.org/10.1016/S01406736(02)09552-1.
Baran, J., M. Baj-Krzyworzeka, K. Weglarczyk, R. Szatanek, M. Zembela, J. Barbasz, A. Czupryna, A. Szczepanik, and M. Zembala. 2010. Circulating tumour-derived microvesicles in plasma of gastric cancer patients. Cancer Immunol. Immunother. 59:841-850. http://dx.doi.org/10.1007/s00262-009-0808-2.

Bauman, D. E., and W. B. Currie. 1980. Partitioning of nutrients during pregnancy and lactation: A review of mechanisms involving homeostasis and homeorhesis. J. Dairy Sci. 63:1514-1529. http:// dx.doi.org/10.3168/jds.S0022-0302(80)83111-0.

Chagas, L. M., J. J. Bass, D. Blache, C. R. Burke, J. K. Kay, D. R. Lindsay, M. C. Lucy, G. B. Martin, S. Meier, F. M. Rhodes, J. R. Roche, W. W. Thatcher, and R. Webb. 2007. New perspectives on the roles of nutrition and metabolic priorities in the subfertility of high-producing dairy cows. J. Dairy Sci. 90:4022-4032. http:// dx.doi.org/10.3168/jds.2006-852.

Chiu, K. M., R. F. Mortensen, A. P. Osmand, and H. Gewurz. 1977. Interactions of alpha1-acid glycoprotein with the immune system. I. Purification and effects upon lymphocyte responsiveness. Immunology 32:997-1005.

Denzer, K., M. J. Kleijmeer, H. F. Heijnen, W. Stoorvogel, and H. J. Geuze. 2000. Exosome: from internal vesicle of the multivesicular body to intercellular signaling device. J. Cell Sci. 113:3365-3374.

Distler, J. H. W., L. C. Huber, S. Gay, O. Distler, and D. S. Pisetsky. 2006. Microparticles as mediators of cellular cross-talk in inflammatory disease. Autoimmunity 39:683-690. http://dx.doi. org/10.1080/08916930601061538.

Farney, J. K., L. K. Mamedova, J. F. Coetzee, J. E. Minton, L. C. Hollis, and B. J. Bradford. 2013. Sodium salicylate treatment in early lactation increases whole-lactation milk and milk fat yield in mature dairy cows. J. Dairy Sci. 96:7709-7718. http://dx.doi. org/10.3168/jds.2013-7088.

Feng, J. K., Y. F. Lu, J. Li, Y. H. Qi, M. L. Yi, and D. Y. Ma. 2015. Upregulation of salivary $\alpha 2$ macroglobulin in patients with type 2 diabetes mellitus. Genet. Mol. Res. 14:2268-2274. http://dx.doi. org/10.4238/2015.March.27.12.

Gallo, A., M. Tandon, I. Alevizos, and G. G. Illei. 2012. The majority of microRNAs detectable in serum and saliva is concentrated in exosomes. PLoS ONE 7:e30679 http://dx.doi.org/10.1371/journal. pone.0030679.

Halasa, T., K. Huijps, O. Østerås, and H. Hogeveen. 2007. Economic effects of bovine mastitis and mastitis management: A review. Vet. Q. 29:18-31. http://dx.doi.org/10.1080/01652176.2007.9695224.

Harris, E. H. 2005. Elevated liver function tests in type 2 diabetes. Clin. Diabetes 23:115-119. http://dx.doi.org/10.2337/diaclin.23.3.115.

Heiser, A., A. Mccarthy, N. Wedlock, S. Meier, J. Kay, C. Walker, M. A. Crookenden, M. D. Mitchell, S. Morgan, K. Watkins, J. J. Loor, and J. R. Roche. 2015. Grazing dairy cows had decreased interferon- $\gamma$, tumor necrosis factor, and interleukin-17, and increased expression of interleukin-10 during the first week after calving. J. Dairy Sci. 98:937-946. http://dx.doi.org/10.3168/ jds.2014-8494.

Hochepied, T., F. G. Berger, H. Baumann, and C. Libert. 2003. $\alpha 1-$ Acid glycoprotein: An acute phase protein with inflammatory and immunomodulating properties. Cytokine Growth Factor Rev. 14:25-34. http://dx.doi.org/10.1016/S1359-6101(02)00054-0.

Ingvartsen, K. L., R. J. Dewhurst, and N. C. Friggens. 2003. On the relationship between lactational performance and health: Is it yield or metabolic imbalance that cause production diseases in dairy cattle? A position paper. Livest. Prod. Sci. 83:277-308. http:// dx.doi.org/10.1016/S0301-6226(03)00110-6.

Kim, H. K., K. S. Song, Y. S. Park, Y. H. Kang, Y. J. Lee, K. R. Lee, H. K. Kim, K. W. Ryu, J. M. Bae, and S. Kim. 2003. Elevated levels of circulating platelet microparticles, VEGF, IL-6 and RANTES in patients with gastric cancer: Possible role of a metastasis predictor. Eur. J. Cancer 39:184-191. http://dx.doi.org/10.1016/ S0959-8049(02)00596-8.

LeBlanc, S. 2010. Monitoring metabolic health of dairy cattle in the transition period. J. Reprod. Dev. 56(Suppl.):S29-S35.

Lewis, G. F., A. Carpentier, K. Adeli, and A. Giacca. 2002. Disordered fat storage and mobilization in the pathogenesis of insulin resis- 
tance and type 2 diabetes. Endocr. Rev. 23:201-229. http://dx.doi. org/10.1210/edrv.23.2.0461.

Looze, C., D. Yui, L. Leung, M. Ingham, M. Kaler, X. Yao, W. W. Wu, R. F. Shen, M. P. Daniels, and S. J. Levine. 2009. Proteomic profiling of human plasma exosomes identifies PPARgamma as an exosome-associated protein. Biochem. Biophys. Res. Commun. 378:433-438. http://dx.doi.org/10.1016/j.bbrc.2008.11.050.

Lucy, M. C., S. McDougall, and D. Nation. 2004. The use of hormonal treatments to improve the reproductive performance of lactating dairy cows in feedlot or pasture-based management systems. Anim. Reprod. Sci. 82-83:495-512. http://dx.doi.org/10.1016/j. anireprosci.2004.05.004.

Lucy, M. C., G. A. Verkerk, B. E. Whyte, K. A. Macdonald, L. Burton, R. T. Cursons, J. R. Roche, and C. W. Holmes. 2009. Somatotropic axis components and nutrient partitioning in genetically diverse dairy cows managed under different feed allowances in a pasture system. J. Dairy Sci. 92:526-539. http://dx.doi.org/10.3168/ jds.2008-1421.

Mathivanan, S., H. Ji, and R. J. Simpson. 2010. Exosomes: Extracellular organelles important in intercellular communication. J. Proteomics 73:1907-1920. http://dx.doi.org/10.1016/j.jprot.2010.06.006.

McNamara, J. P., and J. K. Hillers. 1986a. Regulation of bovine adipose tissue metabolism during lactation. 1. Lipid synthesis in response to increased milk production and decreased energy intake. J. Dairy Sci. 69:3032-3041. http://dx.doi.org/10.3168/jds.S00220302(86)80766-4.

McNamara, J. P., and J. K. Hillers. 1986b. Regulation of bovine adipose tissue metabolism during lactation. 2. Lipolysis response to milk production and energy intake. J. Dairy Sci. 69:3042-3050. http://dx.doi.org/10.3168/jds.S0022-0302(86)80767-6.

McSherry, B. J., F. D. Horney, and J. J. DeGroot. 1970. Plasma fibrinogen levels in normal and sick cows. Can. J. Comp. Med. 34:191-197.

Mertens, I., and L. F. Van Gaal. 2002. Obesity, haemostasis and the fibrinolytic system. Obes. Rev. 3:85-101. http://dx.doi. org/10.1046/j.1467-789X.2002.00056.x.

Povero, D., A. Eguchi, H. Li, C. D. Johnson, B. G. Papouchado, A. Wree, K. Messer, and A. E. Feldstein. 2014. Circulating extracellular vesicles with specific proteome and liver microRNAs are potential biomarkers for liver injury in experimental fatty liver disease. PLoS ONE 9:e113651 http://dx.doi.org/10.1371/journal. pone.0113651.

Reinhardt, T. A., J. D. Lippolis, B. J. Nonnecke, and R. E. Sacco. 2012. Bovine milk exosome proteome. J. Proteomics 75:1486-1492. http://dx.doi.org/10.1016/j.jprot.2011.11.017.

Reinhardt, T. A., R. E. Sacco, B. J. Nonnecke, and J. D. Lippolis. 2013. Bovine milk proteome: quantitative changes in normal milk exosomes, milk fat globule membranes and whey proteomes resulting from Staphylococcus aureus mastitis. J. Proteomics 82:141-154. http://dx.doi.org/10.1016/j.jprot.2013.02.013.

Roche, J. R., D. P. Berry, J. M. Lee, K. A. Macdonald, and R. C. Boston. 2007. Describing the body condition score change between successive calvings: A novel strategy generalizable to diverse cohorts. J. Dairy Sci. 90:4378-4396. http://dx.doi.org/10.3168/ jds.2006-729

Roche, J. R., N. C. Friggens, J. K. Kay, M. W. Fisher, K. J. Stafford, and D. P. Berry. 2009. Invited review: Body condition score and its association with dairy cow productivity, health, and welfare. J. Dairy Sci. 92:5769-5801.

Roche, J. R., S. Meier, A. Heiser, M. D. Mitchell, C. G. Walker, M. A. Crookenden, M. V. V. Riboni, J. J. Loor, and J. K. Kay. 2015. Effects of precalving body condition score and prepartum feeding level on production, reproduction, and health parameters in pasture-based transition dairy cows. J. Dairy Sci. 98:7164-7182. http://dx.doi.org/10.3168/jds.2014-9269.

Salomon, C., M. J. Torres, M. Kobayashi, K. Scholz-Romero, L. Sobrevia, A. Dobierzewska, S. E. Illanes, M. D. Mitchell, and G. E. Rice. 2014a. A gestational profile of placental exosomes in maternal plasma and their effects on endothelial cell migration. PLoS ONE 9:e98667 http://dx.doi.org/10.1371/journal.pone.0098667.

Salomon, C., S. Yee, K. Scholz-Romero, M. Kobayashi, K. Vaswani, D. Kvaskoff, S. E. Illanes, M. D. Mitchell, and G. E. Rice. 2014b. Extravillous trophoblast cells-derived exosomes promote vascular smooth muscle cell migration. Front. Pharmacol. 5:175 http:// dx.doi.org/10.3389/fphar.2014.00175.

Sarker, S., K. Scholz-Romero, A. Perez, S. E. Illanes, M. D. Mitchell, G. E. Rice, and C. Salomon. 2014. Placenta-derived exosomes continuously increase in maternal circulation over the first trimester of pregnancy. J. Transl. Med. 12:204. http://dx.doi. org/10.1186/1479-5876-12-204

Shen, H.-L., Z.-G. Xu, L.-Y. Huang, D. Liu, D.-H. Lin, J.-B. Cao, X. Zhang, Z.-Q. Wang, W.-H. Wang, P.-Y. Yang, and Z.-G. Han. 2009. Liver-specific ZP domain-containing protein (LZP) as a new partner of Tamm-Horsfall protein harbors on renal tubules. Mol. Cell. Biochem. 321:73-83. http://dx.doi.org/http://dx.doi. org/10.1007/s11010-008-9921-3.

Simpson, R. J., J. W. Lim, R. L. Moritz, and S. Mathivanan. 2009. Exosomes: Proteomic insights and diagnostic potential. Expert Rev. Proteomics 6:267-283. http://dx.doi.org/10.1586/epr.09.17.

Subra, C., K. Laulagnier, B. Perret, and M. Record. 2007. Exosome lipidomics unravels lipid sorting at the level of multivesicular bodies. Biochimie 89:205-212. http://dx.doi.org/10.1016/j. biochi.2006.10.014.

Taylor, D. D., and C. Gercel-Taylor. 2008. MicroRNA signatures of tumor-derived exosomes as diagnostic biomarkers of ovarian cancer. Gynecol. Oncol. 110:13-21. http://dx.doi.org/10.1016/j. ygyno.2008.04.033.

Theilgaard-Mönch, K., L. C. Jacobsen, R. Borup, T. Rasmussen, M. D. Bjerregaard, F. C. Nielsen, J. B. Cowland, and N. Borregaard. 2005. The transcriptional program of terminal granulocytic differentiation. Blood 105:1785-1796. http://dx.doi.org/10.1182/ blood-2004-08-3346.

Volkova, O., S. Guselnikov, L. Mechetina, N. Chikaev, K. Baranov, S. Kulemzin, E. Reshetnikova, A. Najakshin, and A. Taranin. 2014. Development and characterization of domain-specific monoclonal antibodies produced against human SLAMF9. Monoclon. Antib. Immunodiagn. Immunother. 33:209-214. http://dx.doi. org/10.1089/mab.2014.0010.

Yokokura, H., T. Demitsu, M. Kakurai, N. Umemoto, R. Azuma, T. Yamada, M. Suzuki, Y. Jimbu, K. Yoneda, N. Ishii, and T. Hashimoto. 2006. Paraneoplastic pemphigus mimicking erosive mucosal lichen planus associated with primary hepatocellular carcinoma. J. Dermatol. 33:842-845. http://dx.doi.org/10.1111/j.13468138.2006.00192.x. 